\title{
A szláv nazális magánhangzót képviselő jövevényszavak átvételének idejérôl és egy számítási próbáról ${ }^{*}$
}

1. Szlavisztikai nézetekről és a témaválasztásról. A nemzetközi szlavisztikában dominánssá vált (bár nem kizárólagos) nézet szerint az ősszláv nyelv felbomlása sokkal korábbi a magyar honfoglalásnál, így a 9. század végén a Kárpátmedencébe érkező magyarság nem az ősszlávval, illetve bizonyos nyelvjárásaival került kapcsolatba, hanem már önálló szláv leánynyelvekkel.

A magyarországi szlavisztikában hosszú időn át szintén ez a felfogás uralkodott. Ennek a szellemében készült el KNIEZSA ISTVÁN alapműve (1955) a magyar nyelv szláv jövevényszavairól, és ezt vallotta például a hazai szlavisztikának egy másik kiemelkedő képviselője, KISS LAJOS még a 20. század végén is (1994: 361). Ennek a jegyében születtek meg a TESz. szláv vonatkozású szócikkei; ebben az EWUng. és az ESz. sem tért el tőle. Természetesnek mondható, hogy az egyetemi tankönyvként is használt magyar nyelvtörténeti szintézisek megfelelő fejezetei szintén átvették a szlavisztika uralkodó álláspontját (BENKÖ 1967, ZSILINSZKY 2003).

Ezzel a hagyományos nézettel fordult szembe ZOLTÁN ANDRÁs már a 20. század végén (1996/2005), a mostani évtizedben pedig számos alkalommal (2013, 2016, 2017 stb.). Ö részben JEVGENYIJ HELIMSZKIJ (1988) teóriája nyomán, de azt lényegesen finomítva és kiegészítve fejtette ki a véleményét arról, milyen lehetett annak a szláv népességnek a nyelve, amelyet a honfoglaló magyarok a Kárpátmedencében találtak.

ZOLTÁN érvelésének alappillére az a - NYIKOLAJ TRUBECKOJtól (1922: 217218) eredő - tétel, hogy az összláv nyelv (teljes) felbomlásáról és a leánynyelvek kialakulásáról csak akkortól fogva beszélhetünk, amikor befejeződött az utolsó közös nagy szláv hangtörténeti változás, a jerekként vagy redukáltakként emlegetett magánhangzóknak ( $b$, b) az eltünése (vagy átalakulása). Ez a 12. századra tehető. Ebből persze az is következik, hogy a magyar nyelv a honfoglalás idején és azután bő kétszáz évig nem önálló szláv nyelvekkel, hanem a felbomlóban lévő kései ősszláv nyelvnek a dialektusaival érintkezett. A magyart érő legerősebb szláv befolyás természetesen a Kárpát-medencei dialektusok szubsztrátum jellegü hatása volt, de ZOLTÁN írásai rendre megemlítik (HELIMSZKIJjel is vitatkozva), hogy persze a szláv „szomszédsággal” folytatott vallási, dinasztikus, katonai, kereskedelmi kapcsolatoknak is voltak nyelvi következményei. (A későbbi, mindmáig fennálló különféle szláv-magyar nyelvi kontaktusok ZOLTÁN elméletének és mostani cikkemnek a témája szempontjából már nem lényegesek.)

ZOLTÁN ANDRÁS szerint a honfoglalás idején és azt követően a magyarság letelepedési helyén kétféle ősszláv dialektussal számolhatunk: a pannóniainak és

* Köszönöm szépen TÓTH VALÉRIA és ZOLTÁN ANDRÁS támogató, hasznos észrevételeket tartalmazó lektori véleményét.

Magyar Nyelv 115. 2019: 271-282. DOI: 10.18349/MagyarNyelv.2019.3.271 
a bolgárosnak nevezhetővel. Számos részletre itt nem térek ki; az érdeklődő olvasó ZOLTÁN említett írásaiból tájékozódhat róluk.

Mondandómat az egyik lényeges témára korlátozom: az olyan szláv jövevényszavak átvételi idejének a kérdésére, amelyeknek az előzménye nazális magánhangzót $(e, q)$ tartalmazott; ezeket a magyar köztudottan (legalábbis az írásképet tekintve) „magánhangzó + nazális mássalhangzó” kapcsolattal vette át: rend, gomba, dorong stb. Az ilyen jövevényszavak átvételének korhoz kötése természetesen szorosan összefügg a szláv denazalizáció jelenségével: azzal, hogy a szóban forgó magánhangzók a szláv nyelvek nagy többségében megváltoztak, (egyebek mellett) elvesztették nazalitásukat.

A következőkben egyrészt arról lesz szó, mit tanít a klasszikus szlavisztika és a magyar nyelvtörténetírás a szláv denazalizációról és a nazálist tükröző jövevényszavaknak a magyarba kerülési idejéröl; másrészt arról, miért és hogyan vonja kétségbe ZOLTÁN ANDRÁS ennek a tanításnak a helyességét (az említett írásain kívül és a nazálisok kérdéskörére összpontosító munkáiként 1. ZOLTÁN 2008, 2011, 2012). Főleg pedig arra a számítási próbára szeretnék reagálni, amelyet KOCSIS MiHÁLY (2018: 68-70) a ZOLTÁN-féle elgondoláshoz kapcsolódva mutatott be. Kocsis cikkét egészében érdekesnek és nagy részében értékesnek is tartom, számítási próbájával azonban sem elvi-módszertani szempontból, sem következtetését illetően nem értek egyet.

\section{A nazális magánhangzót képviselő szláv jövevényszavak átvételének} ideje. Azt az ismert tényt, hogy az egyes szláv nyelvek az ősszláv nazális magánhangzókat általában nem őrizték meg (kivételként a lengyel és részben a szlovén tartható számon), a magyar nyelvtörténeti oktatás is kiemeli (BENKÖ 1967: 287, ZSILINSZKY 2003: 382). Mind a szlavisztikában, mind magyar szempontból gondot okoz azonban a denazalizáció ideje.

A szlavisztika a kormeghatározáshoz két fogódzót használ(vö. pl.: BERNSTEJN 1961: 243-244; ZoLTÁN 2016: 38, 2017: 5). - Az egyik támpont Konsztantinosz híres munkája a birodalom kormányzásáról. Ennek egy részlete a Dnyeper zuhatagainak olyan keleti szláv elnevezéseit említi, amelyek denazalizáltságról tanúskodnak. Ebböl arra lehet következtetni, hogy a folyamat (legalábbis a keleti szláv nyelvjárásokban) a 10. század közepére lezajlott. - A másik fogódzót éppen a magyar nyelvnek azok a honfoglalás idején átvett jövevényszavai szolgáltatják, amelyek igazolják a szláv nazális magánhangzók korabeli, azaz a 9. és a 10. század fordulójára datálható meglétét.

A két időpont közelsége azonban kételkedést támaszt a kormeghatározás helyességében. A denazalizáció ugyanis bonyolult, feltehetőleg fokozatosan és lassú ütemben végbemenő változás volt. Az ilyenre pedig fél évszázad nyilván kevés. Szláv összehasonlító nyelvtanában természetesen SZAMUIL BERNSTEJN is felismeri és elismeri ezt a nehézséget, és persze megpróbál kiutat keresni a csapdahelyzetből (1961: 243-245). Ehhez azt a feltételezést hívja segítségül, hogy a denazalizáció folyamata még a magyar honfoglalás előtt megkezdődött, és a szláv nyelvek (nyelvjárások) nagy részében a 9. és a 10. században akár kétszáz éven át is tarthatott. Mint a bolgár nyelvjárástörténet kiváló szakértője nem mulasztja el 
annak a kiemelését, hogy a bolgárban a denazalizáció később, igen lassan, a 11. századtól akár a 14. századig is elhúzódva ment végbe. Ebből azonban a magyar nyelv nazálisos jövevényszavaira nézve nem von le következtetést.

A honfoglalást és a konsztantinoszi mủvet összekötő időszakasz rövidsége mag y a r vo n a tk o zás ban szintén problémát okoz, hiszen felveti a kérdést: lehetséges volt-e mindössze néhány évtized alatt annak a s zá m o s jö ve vé n y s z ó nak az átvétele, amelyek a szláv nazális magánhangzóknak a korukbeli meglétét tanúsítják? (A magyar nyelv érintett jövevényszavaiból bö - csaknem ötven közszóból álló és helynevekkel is megtoldott - listát közöl HeLIMSZKIJ [1988: 348-349].)

A hagyományos szlavisztika és a magyar nyelvtörténetírás - egyfelöl igazodva ahhoz a feltételezéshez, hogy az orrhangú magánhangzók denazalizációja a szláv nyelvek (nyelvjárások) nagy részében a 11. század előtt befejeződött; másrészt figyelembe véve azt, hogy a nazálisos jövevényszavak átvétele a honfoglaláskor nem történhetett meg ,azonnal”, hanem időre volt szükség hozzá - azzal számol, hogy az érintett jövevényszavak a 10 . s zá zad vége e lőtt kerülhettek át a magyarba. Ezt az álláspontot képviseli KNIEZSA monográfiája (1955), és ezt a határpontot ismételgetik a TESz., az EWUng. és az ESz. megfelelő szócikkei - ZOLTÁN ANDRÁS kifejezésével élve: ,imamalomszerủen” (ZOLTÁN 2012: 385). Természetesen ez vagy ezzel egyenértékủ dátum jelenik meg (a legújabbat részben kivéve) a magyar nyelvtörténeti tankönyvekben is (BENKÖ 1967: 287, ZSILINSZKY 2003: 382; de vö. GERSTNER 2018: 254).

Maga ZOLTÁN ANDRÁS abban a fontos tanulmányában, amelyben a 20. század végén az ősszláv nyelv felbomlásának ügyében szembefordul az uralkodó nézettel, a denazalizációt és a nazálisos jövevényszavakat illetően még nem ad hangot a hagyományos felfogás bírálatának, noha a 10. század végi határpontot mellőzi, és ezzel meg is hosszabbítja a lehetséges szóátvételi időt: „Régi szláv jövevényszavaink legnagyobb tömege tehát szubsztrátum jellegü nyelvi kontaktusok eredménye, mintegy nyelvi örökség azok után a szlávok után, akiket a magyarság a Kárpát-medencében a X-XI. században nyelvileg asszimilált. Ebbe a legrégibb rétegbe tartoznak kétségtelenül (a nyelvemlékeinkben való felbukkanásuk időpontjától függetlenül) azok a szavak, amelyek a magyarban a szlávban még meglévő nazális magánhangzókat $(e, q)$ tükrözik, ezek ugyanis a környezetünkben élő szlávok nyelvében legkésőbb a XI. században elvesztették a nazális rezonanciát és nyelvenként különböző módon egyszerü magánhangzókká váltak" (ZOLTÁN 1996/2005: 20). - Már itt szeretném kiemelni a „, ké t s é g t e le n ül (a nyelvemlékeinkben való felbukkanásuk időpontjától függ e t l e n ü l)" részletet, ennek ugyanis később, Kocsis MiHÁLY számítási próbájának bemutatásával kapcsolatban fontos szerepe lesz.

Abban a recenziójában, amely KIRÁLY PÉTERnek a kettős honfoglalás elméletét képviselő könyvéről szól, ZOLTÁN ANDRÁS - részben BERNSTEJN (1961: 243244) nyomán - a „kronológiai feszültség”, „keltezési ellentmondás” kifejezéseket használva ráirányítja a figyelmet arra a nehézségre, amely a szláv denazalizációt és azzal szoros összefüggésben a nazálisok nyomát mutató jövevényszavaknak az átvételét illetően az ezekre a folyamatokra jutó idő rövidségében nyilvánul 
meg (ZOLTÁN 2008: 357-358). Ugyanott (358) a recenzens jelzi, hogy a kettős honfoglalás teóriájának elfogadása szabadulást jelentene az időcsapdából, hiszen „ha egy-két évszázaddal korábban kezdődött a szláv-magyar együttélés a Kárpátmedencében, [...] akkor kényelmesen volt idő átvenni az itteni szlávoktól a még nazális magánhangzókat tartalmazó korai szláv jövevényszavainkat”.

Erre a lehetőségre ZOLTÁN ANDRÁS néhány évvel később a BERNSTEJNemlékkonferencia kötetében is felhívja a figyelmet (2011: 34). Fontos újdonságként azonban itt bemutat egy másfajta kiutat is a kronológiai csapdából. Ez a megoldási elképzelés azon alapul, hogy a honfoglalást követő időben a magyarság a Kárpát-medencében nemcsak a pannóniai szláv dialektusnak, hanem egy bolgárosnak a beszélőivel is kapcsolatba került, méghozzá nemcsak délkeleten, hanem a nyelvterület központibb részén is. Mivel pedig a bolgár(os) denazalizáció (mint fentebb én is említettem) BERNSTEJN szerint a 11. században kezdődött, és akár a 14. századig is elhúzódhatott, ZOLTÁN (2011: 33) levonja azt a kézenfekvő következtetést, hogy a magyarok a bolgáros dialektusból a 11. században, sőt még később is átvehettek nazális magánhangzójú jövevényszavakat. A szóátvétel ideje tehát nemcsak visszafelé, hanem ebben az irányban is meghosszabbítható. Ha a kétféle irányban nyerhető időt egyesítjük, akkor a magyar nyelvterület egy részén körülbelül a 8. és a 12. század között lehetett mód nazális magánhangzójú szláv jövevényszavak átvételére (ZOLTÁN 2011: 34).

Az időkelepcéből való kétféle kivezető utat azután ZOLTÁN magyar nyelven is bemutatja több munkájában $(2012$, 2016: 37-40, 2017: 5-6).

A szegedi nyelvtörténeti konferencián tartott előadásában csak a „bolgáros” lehetöséget hozza szóba, viszont hozzáfúz egy érdekes kiegészítést a nazálisos és a denazalizált formát képviselő párokról: „Mindebből az következik, hogy a szláv nazálist tükröző jövevényszavaink nem feltétlenül a honfoglalást közvetlenül követő néhány évtizedben kerültek átvételre (a Dunántúlon), hanem a 11-13. század folyamán is (a nyelvterület keleti, északkeleti részén), vagyis a menszáros $\sim$ mészáros, donga duga párok nem feltétlenül különböző k o r b a n, hanem éppolyan valószínüséggel különböző h e ly e n párhuzamosan átvett alakváltozatok is lehetnek" (ZOLTÁN 2013: 196) - az idézetbeli kiemelések tőle származnak. Én pedig a visszatérö „n e m feltét le n ül” kifejezést szeretném kiemelni, mivel szépen mutatja: a szerző tisztában van azzal, hogy az ő felvetésével a hagyományosan számításba vett lehetőségek bővülnek, de nem törlődnek. Nem kell tehát elvetnünk azt a feltevést, hogy a magyarba a honfoglaláshoz viszonylag közeli időpontban és a Dunántúlon is kerülhettek át olyan jövevényszavak, amelyek a szláv orrhangú magánhangzók korukbeli meglétét jelzik; másrészt továbbra sincs kizárva az, hogy a donga duga típusú kettősség mögött kronológiai különbség is állhat.

ZOLTÁN ANDRÁSnak azok a gondolatai, amelyek két irányban is kivezető utat kínálnak a többször említett kormeghatározási kelepcéből, a magyar nyelvtörténetírásban és a tárgy oktatásában nem maradtak visszhangtalanok. Az egyetemi tankönyvként is használt új nyelvtörténeti kézikönyvben GERSTNER KÁROLY a szláv jövevényszavakról szólva (2018: 253-255) ismerteti őket, lehetségesként számol velük - igaz, óvatosan. 
3. Kérdések és megjegyzések. Mielött rátérek annak a számítási próbának a bemutatására, amelyet KOCSIS MıHÁLY a szláv nazális magánhangzókat tükröző jövevényszavakkal kapcsolatban elvégzett, szeretnék egy-két kérdést, illetve megjegyzést füzni az előző pontban írtakhoz.

Olyan kérdéssel kezdem, amely a magyarba átkerült jövevényszavakhoz csak közvetetten kötődik. Nem vitás, hogy a Konsztantinosznál felbukkanó denazalizált helynévadatok fontosak. De csekély számukhoz képest nincs-e eltúlozva a jelentőségük? Okvetlenül azt jelzik-e, hogy a keleti szláv nyelvjárásokban a 10. század közepére befejeződött a denazalizáció? Úgy vélem, nem zárhatjuk ki annak a lehetöségét, hogy abban az időben ezeknek a dialektusoknak a nyelvhasználata még ingadozott, orrhangú és denazalizált alakok versengtek egymással, és ebből a szövegből történetesen neológ formák dokumentálhatók. Adatok hiányában ez persze csupán feltevés marad, de talán ilyesmire gondolt BERNSTEJN is, amikor ezt írta: „Feltételezhető, hogy a denazalizáció a 10. századnál korábban kezdődött. A folyamat sok szláv nyelvben a 9. és a 10. század folyamán (azaz két évszázadon át) zajlott. Nincsenek olyan tények, amelyek megzavarnának bennünket abban, hogy elfogadjuk ezt a kormeghatározást az óorosz nyelvre [ti. a keleti szláv dialektusokra - H. L.] nézve" (BERNSTEJN 1961: 244; az orosz eredetit a saját fordításomban idézve).

Láthattuk ugyanakkor azt, hogy a konsztantinoszi denazalizált formák időbeli közelsége a magyar honfoglaláshoz magát BERNSTEJNt is aggasztja. ZOLTÁN pedig ezt írja: „Lehetséges [...], hogy a keleti szlávokhoz hasonlóan a pannóniai szlávok nyelvében is megtörtént a denazalizáció már a 10. század közepére" (2013: 196). Erre szerintem azt mondhatjuk: igen, lehetséges, de még akkor sem biztos, ha elfogadjuk, hogy a keleti szlávoknál addigra valóban lezárult a folyamat. Nem ismerek olyan tényt, amely megakadályozná annak a feltételezését, hogy a denazalizáció a pannóniai szlávoknál valamivel tovább tartott, mint keleti rokonaiknál, így a hagyományban szereplö 10. század végi határt sem gondolom valószínűtlenül későinek. Ha pedig ezt elfogadjuk, akkor (a kettős honfoglalás teóriájától most eltekintve) a Dunántúlon is száz év állt a magyarság rendelkezésére a nazális magánhangzójú jövevényszavak átvételéhez.

Mint az előző pont végéhez közeledve kiemeltem, ZOLTÁN ANDRÁs a kronológiai kiútkereséssel nem zárja ki annak a lehetőségét, hogy a honfoglalás után viszonylag rövid idővel is kerülhettek át a magyarba a szláv nazális magánhangzókat képviselő jövevényszavak. Van azonban olyan hely is, ahol élcelődik a gyors szóátvételt feltételező elképzelésen: „Azért teszik a szlavisták a denazalizációt a 10. század végére, hogy adjanak némi időt arra, hogy a magyarok a viszonylag nagy számú, még a szláv nazálisokat tükröző jövevényszót az itt talált szlávoktól átvegyék [...]. Más megközelítésből úgy is mondhatnánk, hogy e felfogás szerint a magyarok elődei csak azért siettek elfoglalni a Kárpát-medencét a 9. század végén, hogy még mint valami zárványt megörizhessék nyelvükben az immár eltünőben lévő szláv nazális magánhangzók lenyomatát" (ZOLTÁN 2013: 196). A retorikailag hatásos és kétségtelenül szellemes gondolat azonban a visszájára is fordítható, valahogy így: „A magyarok már a honfoglaláskor is hallották a nazális magánhangzójú szláv szavakat, de jó ideig szándékosan nem törődtek velük, mert utódaiknak akarták meghagyni azt a dicsőséget, hogy a bolgáros dialektusból átvehessék őket." 
Szeretnék egy szótárírói megjegyzést is tenni. Mivel ZOLTÁN ANDRÁS a nevezetes 10. század végi határpontot nem fogadja el, teljesen érthető, hogy annak ismételgetését az etimológiai szótárakban monotonnak, imamalomszerünek érzi. Lexikográfusi szemmel és a tartalomtól függetlenül nézve azonban maga az ismételgetés nem tekinthető hibának. Sokan ugyanis nem „csokorban” olvassák az érintett szócikkeket, hanem egyet-egyet tanulmányoznak valamilyen okból, ezért jó, ha a feltételezett átvételi időpont minden szükséges helyen szerepel. Ebböl a szempontból az EWUng. (és annak nyomán az ESz.) következetesebb KNIEZSA monográfiájánál (1955), sőt a TESz.-nél is.

4. Az adatoltságon alapuló számítási próba. ZOLTÁN ANDRÁS tanulmányai közül a Magyar Nyelvtudományi Társaság közgyülésén tartott elöadás írott változata (2017) volt az, amelyet Kocsis MIHÁLy (2018: 68-70) hivatkozási alapnak tekintett a számítási próbájának bemutatásakor. A kísérlet gondolatának megszületéséről így ír: „Az ESz.-t lapozgatva támadt az az ötletünk, hogy kiszámoljuk: a szótár adatai szerint átlagosan mennyi idő telt el egy nazálist tartalmazó szláv jövevényszó feltételezett átvételének és valamely írott forrásban való első felbukkanásának időpontja között" (KoCSIS 2018: 68).

KOCSIS MiHÁLY az ESz. címszavai között 29 olyat talált, amely („magánhangzó + nazális mássalhangzó" kapcsolattal) képviseli valamelyik szláv nazális magánhangzót. Pontosabban két esetben azt kell mondanunk, hogy képviselheti: a rongál ugyanis „,csak” valószínúleg szláv származású; a rombol pedig vitatott eredetü, és a két lehetőség közül az egyik a szláv származtatás. Ezt a két szót KoCsIS ki is zárta a statisztikai próbájából. - Itt jegyzem meg, hogy 29-es listáját még két szóval megtoldhatta volna. Közülük a szentel a rombol-hoz hasonlóan vitatott eredetü, a mészáros ( menszáros)-nak pedig a címszóalakja nem tartalmazza a nazálist. Ezt a két esetet csupán kiegészítésül említem meg; ezek a szavak minden bizonnyal akkor is kimaradtak volna KoCSIS tényleges számításából, ha szóba hozza őket.

Mivel KoCSIS MıHÁLY azokra a szláv jövevényszavakra kívánt összpontosítani, amelyeknek az átvételi idejével kapcsolatban az ESz. - közvetlenül vagy közvetve - a 10. század végét jelzi határpontnak, listájának a maradék 27 eleméből még hármat kihagyott. A lengyel-t azért, mert az ESz. honfoglalás előtti óorosz jövevénynek minősíti. A sánta névszót azért, mert annak a valószínü átvételi idejeként az ESz. KoCSIS szerint a 10. század első felét jelöli meg. Ez így azonban erősen pontatlan. A szótár ugyanis nem ezt állítja, hanem azt, hogy a sánta elvonás eredménye a sántál 'sántít' igéből, valójában ez az ige a szláv jövevényszó, és ennek a valószínü átvételi ideje a 10. század első fele. Mindennek egyébként „csak” etimológiai és lexikográfiai szemszögből van jelentősége, hiszen a szócikk KoCSIS számításában nem jutott képviselethez. - A harmadik kimaradó szó a pisztráng. Az ESz. azt írja róla, hogy a 10. század előtt került át a magyarba. KOCSIS itt helyesen, de túl szerényen veti fel a sajtóhibának, a vége szó kimaradásának a lehetőségét. Mindenesetre a szöveget tiszteletben tartva a pisztráng-ot is kihagyta a tényleges számítás szereplői közül. 
A rostálás után 24 jövevényszó maradt a vizsgálathoz. Az ESz. 16-uknak az esetében nevezi meg átvételi határpontként a 10. század végét, a további 8-cal kapcsolatban közvetve (a fogalmazásmóddal, analógiával) utal erre.

A számításba vehető jövevényszavakat KoCSIS (már a rostálás előtt) időrendbe állította első írásbeli felbukkanásuk szerint. Első adatként a kérdőjeles tulajdonnevet is elfogadta (vö. galamb, konc, rend, dorong). - Visszatérő pontatlanságként szerepel az a cikkben, hogy a szótárbeli kérdőjel „az adat hitelességét gyengíti". Ez olyasmit is sugallhat, hogy az adattal kapcsolatban a hamisításnak vagy a téves olvasatnak a gyanúja vetődik fel. Valójában azonban a kérdőjel azt jelzi, hogy az adatnak az adott címszóhoz tartozása nem biztos. Valószínűleg KoCSIS MIHÁLY sem gondolja ezt másképpen; valamelyest félreérthető fogalmazása a számításának eredményét és érthetőségét nem befolyásolja.

KOCSIS MIHÁLY minden vizsgált (vagyis 24) jövevényszó esetében összevetette az első adat évszámát a 10. század utolsó évével, azaz 1000-rel, és a mért különbségeket átlagolta. Ezt a számítást (a fentebb említett okból) 16, illetve $16+8=$ 24 szóra nézve is elvégezte. Az 1000-es évszámhoz hasonlítva a szükebb csoport átlagos különbségét 271 évnyinek, a tágabbét pedig 255 évnyinek találta.

A végeredményből így vonja le a következtetést: „Mindez pedig azt jelenti, hogy - tekintettel a két végpont kezelésének módjára: a különbség minden lehetséges eszközzel való csökkentésére [ezen a kérdőjeles adatok beszámítását érti] ki kell mondanunk: a nazálist tükröző szláv szavaink (átlagosan) majd 300 évvel később dokumentáltak, mint átvételük feltételezett ideje. Ebből pedig az következik, hogy az időpont meghatározásához egy 10. századra feltételezett szláv denazalizáció aligha ad megbízható támpontot. (Ennek az állításnak az igazságán nem változtat az a tény sem, hogy az Árpád-korból szerény mennyiségủ forrásanyag maradt ránk.) A hangtani változás hipotetikus és az írott források tényleges keletkezési ideje túlságosan messze esik egymástól" (KoCsIs 2018: 69-70). A megoldást ZOLTÁN elméletének alkalmazásában látja: „kérdés, hogy ez a nagy időintervallum nem csökkenthető-e valamely más [mármint a hagyományos kormeghatározáshoz képest más] magyarázattal. ZOLTÁN ANDRÁS elmélete, mely a bolgár jövevényszavak nagy számát nem marginális érintkezéssel vagy rövid ideig tartó kapcsolattal, hanem több évszázados együttéléssel indokolja, sikerrel hidalja át ezt a roppant időbeni távolságot" (KoCsIS 2018: 70). Azt hiszem, itt érdemes még megtoldani az idézeteket azzal a részlettel, amelyben Kocsis cikkének a bevezetőjében a számunkra most fontos célját megjelöli: „újabb adalékkal kívánjuk megerősíteni a 10. századnál nem későbbinek tartott átvételi időpont vitathatóságát" (2018: 68).

5. A próba értékelése. Az értékelést azzal kezdem, hogy a túlzóbbakkal szemben ,az átvételi időpont vitathatósága” megfogalmazással értek egyet. Ez van összhangban azzal a visszatérő (a 2. pontban idézett és kiemelt) „,nem feltétlenül” kifejezéssel is, amellyel ZOLTÁN (2013: 196) a hagyományos állításokkal, azoknak a kizárólagosságával szembefordul.

KOCSIS MIHÁLY sokallja azt a majdnem 300 évnyi különbséget, amelyet a nazálisos szláv jövevényszavak átlagos dokumentálhatósági időpontja és a nevezetes 
10. század végi határpont között mért, ezért az utóbbit nem tartja megbízható támpontnak. Azt azonban nem árulja el, mekkora eltérést gondolna elfogadhatónak ahhoz, hogy a hagyományos álláspontot fenntarthassuk. Véleményem szerint egyfelöl helytelen, hogy hallgat erről, hiszen ha ilyen nagy jelentőséget tulajdonít az adatolási időnek, akkor az általa elvárt átlagos értéket logikus és illő volna közölnie. Másfelől viszont nagyon is helyesen teszi, hogy a „megkövetelt” időkülönbségről nem szól, hiszen elvileg, általánosságban sem lehetséges vagy célszerü efféle konkrét elvárható határidőt megadni, az ómagyar korra nézve pedig gyakorlatibb okból is különösen kockázatos lenne.

Itt érkezünk el ahhoz a ponthoz, amelyen KOCSIS MiHÁLY szemlélete értetlenséget vált ki belőlem: ,az időpont meghatározásához egy 10. századra feltételezett szláv denazalizáció aligha ad megbízható támpontot. (Ennek az állításnak az igazságán nem válto ztat az a tény sem, hogy az Árpád-korból szerény mennyiségü forrásanyag maradt ránk.)" (KoCSIS 2018: 70; a kiemelés tőlem való). A zárójelbeli megjegyzésnek természetesen éppen az ellenkezője igaz: az Árpádkori nyelvemlékanyag mennyiségének és jellegének itt ku l c s s z e re pe van.

Ezzel kapcsolatban először hadd ismételjek meg rövidítve egy olyan részletet, amelyet a 2. pontban kiemeléssel idéztem ZOLTÁN ANDRÁS ezredvégi tanulmányából: „Régi szláv jövevényszavaink legnagyobb tömege [...] nyelvi örökség azok után a szlávok után, akiket a magyarság a Kárpát-medencében a X-XI. században nyelvileg asszimilált. Ebbe a legrégibb rétegbe tartoznak kétségtelenül (a nyelvemlékeinkben való felbukkanásuk időpontjától fü g g e tl le ü 1 ) azok a szavak, amelyek a magyarban a szlávban még meglévő nazális magánhangzókat (e, q) tükrözik" (1996/2005: 20 - a kiemelés tőlem való). - Az igaz, hogy ZoLTÁN ennek a kijelentésének idején éppen a nazálisos jövevényszavak ügyében még nem szállt erőteljesen szembe a hagyományos nézettel, az adatolási időt azonban az újabb munkáiban sem használta érvként a hagyományban élőnél későbbi átvétel mellett. Minden bizonnyal azért nem, mert tisztában van azzal, hogy erre az érintett évszázadokat tekintve nem alapozhat.

A KOCSIS MIHÁLY elemzéséből kiemelt zárójeles megjegyzésből viszont úgy tünik, hogy ő - ZOLTÁNnal ellentétben - nem eléggé veszi tekintetbe az Árpádkor kínálta nyelvemlékek tulajdonságait. A jelek szerint alábecsüli azt a közismert tényt, hogy a korai ómagyarból sem gazdag anyagú szójegyzékek, sem pedig terjedelmes szövegemlékek (kódexek) nem maradtak fenn; a korabeli szövegemlékek igen csekély számúak és rövidek. Mivel tehát a korszak írásbelisége az oklevélbeli szórványokon kívül alig kínál lehetőséget a szavak dokumentálására, a nazálisos szláv jövevényeknek a 13. század második felére eső átlagos adatoltságát nem merném késeinek mondani, sőt inkább „szép teljesítmény”-nek minősítem. Ö n m a g á b a n semmiképpen sem indokolja a 10. század végi határpont tagadását.

Hogy az ómagyar, különösen a korai ómagyar szókészletet vizsgálva nagyon óvatosan kell bánni mind az adatoltsággal szemben támasztott igénnyel, mind a belőle levont következtetéssel, azt más irányból, a szláv jövevényszavak köréből kilépve is szeretném bemutatni.

Ha KoCSIS MiHÁLY (2018: 70) az ezredfordulóhoz képest „roppant időbeni távolság"-nak tartja a nazálisos szláv jövevényszavaknak az általa mért, a 13. szá- 
zad második felére eső átlagos adatoltsági idejét, akkor vajon mikorra tenné a honfoglalás előtti jövevényszavaknak, például az irániaknak a kívánatos dokumentáltságát? Ezt persze nem tudhatom, már csak azért sem, mert a kívánt adatoltsági átlagot a szláv jövevényszavakat illetően sem nevezi meg. Ha azonban igyekszem ahhoz alkalmazkodni, ahogyan Kocsis a saját számításának eredményét kommentálja, akkor - persze már a magam felelősségére - azt kell mondanom, hogy a honfoglalás előtti jövevényszavaktól a 11. század vége előtti átlagos adatoltság mindenképpen elvárható lenne.

Hogy a valódi dokumentáltság átlagos idejét meghatározhassam, az ESz. alapján - igaz, nem a szótár végiglapozásával, hanem a mutatórész felhasználásával - összeállítottam a biztos eredeztetésủ iráni jövevényszavak listáját. Ebbe 10 címszó került. Első írásbeli előfordulásuk évszámát olyan elvek szerint rendeltem hozzájuk (a tulajdonneveknek, a kérdőjeles adatoknak stb. kezelésmódját illetően), ahogyan azt Kocsis tette. Az átlagos adatoltság éveként 1228-at kaptam. Ez az időpont néhány évtizeddel korábbi a nazálisos szláv jövevényszavakhoz tartozónál, de szintén 13. századi, vagyis az általam hipotetikusan felvetett 11 . századinál sokkal későbbi. Pusztán ezért azonban nyilvánvalóan nem kell kételkednünk sem a felmérés szereplőinek iráni származásában, sem a honfoglalás előtti voltukban.

És vajon milyen átlagos adatoltságot kívánhatnánk meg az alapnyelvből örökölt szókészlet elemeitől, például az ugor réteghez tartozóktól? A magyarság a honfoglalás előtt mintegy kétezer évvel (vagy akár többel) szakadt ki az ugor közösségből. Ebből kiindulva pusztán logikai alapon és csak a Kárpát-medencébe való 9. század végi megérkezésre figyelve elvárhatnánk, hogy az ugor korból örökölt elemek a honfoglalás első pillanatától fogva adatolva legyenek. De ha nem esünk effajta abszurd túlzásba, azt a hipotetikus határidőt, amelyet az iráni jövevényszavak esetében, elvileg itt is megkövetelhetnénk. Ez pedig a 11. század vége volna.

Az ESz. mutatójának segítségével összeállítottam azoknak a címszavaknak a listáját, amelyek a szótár szerint biztosan az alapnyelvi örökség u g or rétegébe tartoznak. Nem vettem be közéjük az ,ugor tő + magyar képző" felépítésü elemeket. Így a listában 43 szó kaphatott helyet. Első előfordulásuk évszámát ugyanúgy rendeltem hozzájuk, mint az iráni jövevényszavak esetében. Az átlagos adatoltsági évszám itt 1221 lett, vagyis majdnem ugyanaz, mint az iráni jövevényszavak csoportjában. Ez persze azt jelenti, hogy itt is igen nagy a késés a hipotetikusan elvárt határidőhöz képest.

Láthatjuk tehát, hogy a korai ómagyar kor sajátosságai nem engedik meg, hogy az egyes eredetkategóriák képviselői a tőlük elvileg elvárhatóhoz közeli időben jelenjenek meg az írásbeliségben.

Két kis kontrollpróbám igazolta azt az állításomat, hogy a korszak jellemzőit figyelembe véve a nazálisos szláv jövevényszavak átlagos felbukkanási ideje nincs szokatlanul messze a nevezetes 10 . század végi határponttól. A két időpont távolsága ö $\mathrm{nmag}$ áb a n nem indokolja a szláv nazális magánhangzót tükröző jövevényszavak átvételi idejére vonatkozó hagyományos elképzelés elvetését. Ezzel persze nem állítom azt, hogy okvetlenül ragaszkodni kell ehhez az elmélethez, elvetve ZOLTÁN ANDRÁSét. Azt viszont hangsúlyozom, hogy K o C S I S M i H Á LY számítása a hagyományos nézet cáfolatára nem alkalmas. 
6. Kitekintés. Azokkal a gondolatokkal, amelyekben ZOLTÁN ANDRÁs a honfoglalás idejének és az azt követő egy-két évszázadnak a szláv-magyar kapcsolataival foglalkozik, a 2005-ben megjelent tanulmánykötetének recenzióján dolgozva ismerkedtem meg elöször közelebbről (vö. HoRVÁTH 2007). Már akkor nyilvánvaló volt, hogy egy leendő etimológiai szótárban a felvetéseit figyelembe kell venni, mérlegre kell tenni: mind általánosabb, elvi szempontból, mind az egyes érintett jövevényszókat illetően. Most, az Új magyar etimológiai szótár (= ÚESz. $)^{1}$ készítése közben ez a feladat aktuálissá vált. Elvégzése lexikográfiai vonatkozásban is fejtörést okoz. A szócikkek etimológiai szakaszában ugyanis a müfaj adta szük keretben egy-egy összegző formulába, néhány nyelvi adatba és egy-két magyarázó, kiegészítő mondatba kell süríteni mindazt, aminek a taglalására egy tanulmány - akár ZOLTÁNé, akár másé; a véleményéhez csatlakozó vagy éppen vele vitatkozó - sokkal tágabb teret biztosít.

KOCSIS MiHÁLY számítási próbáját pedig - annak ellenére, hogy sem a korai ómagyar kor jellegének elhanyagolása miatt, sem (ezzel persze összefüggően) a következtetésében nem értek egyet vele - érdekes paradoxonként az egyetemi oktatásban hasznosíthatónak gondolom. Úgy vélem, az ilyenféle kísérletek elvégeztetésével (szemináriumi dolgozat vagy kiselőadás formájában) fel lehet kelteni a hallgatók érdeklődését a nyelvtörténeti kutatás, az etimológia és a lexikográfia iránt.

Kulcsszók: szláv nazális magánhangzók, denazalizáció, szláv jövevényszavak, kormeghatározás, adatoltságon alapuló számítási próba.

\section{Hivatkozott irodalom}

BENKÖ LORÁND 1967. A szláv jövevényszavak. In: BÁRCZI GÉZA - BENKŐ LORÁND BERRÁR JolÁN, A magyar nyelv története. Tankönyvkiadó, Budapest. 285-289.

BERNSTEJN, SZAMUIL BORISZOVICS [= БЕРНШтЕйН, С. Б.] 1961. Очерк сравнительной грамматики славянских языков. Издательство Академии Наук CCCP, Moszkva [= Москва].

ESz. = Etimológiai szótár. Föszerk. ZAICZ GÁBOR. Tinta Könyvkiadó, Budapest, 2006. EWUng. = Etymologisches Wörterbuch des Ungarischen 1-2. Hrsg. BENKÖ, LORÁND. Akadémiai Kiadó, Budapest, 1993-1995.

Gerstner KÁRoly 2018. Szókészlettörténet. In: Kiss JenŐ - PuszTAI Ferenc szerk., $A$ magyar nyelvtörténet kézikönyve. Tinta Könyvkiadó, Budapest. 249-270.

HelimsZKIJ, JEVGENYIJ ARNOLDOVICS [= Хелимский, E. А.] 1988. Венгерский язык как источник для праславянской реконструкции и реконструкции славянского языка Паннонии. In: Толстой, Н. И. ред., Славянское языкознание: Х Международный съезд славистов, София, сентябрь 1988 г., Доклады советской делегаиии. Nauka, Moszkva [= Наука, Москва]. 347-368.

HORVÁTH LÁsZló 2007. Zoltán András: Szavak, szólások, szövegek. Nyelvészeti és filológiai tanulmányok. [Recenzió.] Magyar Nyelvőr 131: 380-383.

${ }^{1}$ Ez a szótár az NKFI K 124127. számú projektumának keretében az MTA Nyelvtudományi Intézetben készül GERSTNER KÁROLY irányításával. A munkálatokban, amelyekhez mostani tanulmányom is szorosan kapcsolódik, szenior kutatóként veszek részt. 
KISS LAJOS 1994. Néhány szlavisztikai müszóról (ősszláv nyelv, ószláv nyelv, egyházi szláv nyelv, óorosz nyelv). Magyar Nyelv 90: 361-363.

KNIEZSA ISTVÁN 1955. A magyar nyelv szláv jövevényszavai I/1-2. Akadémiai Kiadó, Budapest.

Kocsis MiHÁLY 2018. A szláv nazálisok és a huszár. Magyar Nyelv 114: 68-77.

TESz. = A magyar nyelv történeti-etimológiai szótára 1-3. Főszerk. BENKÖ LORÁND. Akadémiai Kiadó, Budapest, 1967-1976.

Trubeckoj, Nyikolaj Szergejevics [= TrubetzKoy, N. S.] 1922. Essai sur la chronologie de certains faits phonétiques du slave commun. Revue des Études Slaves 2: 217-234.

ZOLTÁN ANDRÁS 1996/2005. A magyar-szláv érintkezések kezdetei és fázisai. In: ZoLTÁN ANDRÁs, Szavak, szólások, szövegek. Nyelvészeti és filológiai tanulmányok. Lucidus Kiadó, Budapest. 11-27.

ZoLTÁN ANDRÁs 2008. Király Péter, A honalapítás vitás eseményei. A kalandozások és a honfoglalás éve. [Recenzió.] Magyar Nyelv 104: 355-359.

ZOLTÁN ANDRÁS [= ЗОЛтAH, АНДРАШ] 2011. Вопрос о древнейшем пласте славянских заимствований в венгерском языке и хронология деназализации носовых в славянском. In: ЖУРАВЛЕВ, А. Ф. - АНАНЬЕВА, Н. Е. ред., Современная славистика и научное наследие С. Б. Бернштейна. Тезисы докладов международной научной конференщии, посвященной 100-летию со дня рождения выдающегося отечественного слависта д. ф. н. проф, С. Б. Бернштейна. Moszkva [= Moсква]. 31-35.

ZOLTÁN ANDRÁS 2012. Szláv nazálisokat tükröző régi szláv jövevényszavaink időrendje. In: KoCsIS MiHÁly - MAJOROS HENRIETTA szerk., Legendák, kódexek, források. Tanulmányok a 80 esztendös H. Tóth Imre tiszteletére. Szegedi Tudományegyetem Szláv Intézet, Szeged. 383-387.

ZOLTÁN ANDRÁS 2013. Legrégibb szláv jövevényszavaink szláv dialektológiai hátteréhez. In: FORGÁCS TAMÁs - NÉMETH MiKLÓs - SinKOVICS BALÁZS szerk., A nyelvtörténeti kutatások újabb eredményei VII. Szegedi Tudományegyetem BTK Magyar Nyelvészeti Tanszék, Szeged. 193-198.

ZOLTÁN ANDRÁS 2016. A Kárpát-medencei szlávok nyelvéről a honfoglalás korában. In: É. KISS KATALIN - HEGEdÜS ATTILA - PINTÉR LILlA szerk., Nyelvelmélet és kontaktológia 3. Szent István Társulat, Budapest-Piliscsaba. 33-45.

ZOLTÁN ANDRÁs 2017. Szláv jövevényszavaink néhány időrendi és nyelvföldrajzi kérdése. Magyar Nyelv 113: 1-9.

ZSILINSZKY ÉVA 2003. A szláv jövevényszavak [Az ómagyar kor]. In: KISS JENŐ - PUSZTAI FERENC szerk., Magyar nyelvtörténet. Osiris Kiadó, Budapest. 381-384.

\section{On the time of borrowing of loanwords involving Slavic nasal vowels and a method of calculation}

One of the topics of the present paper is the time of denasalization of Slavic nasal vowels $(e$, q) and, correspondingly, the timing of Slavic loanwords in Hungarian that still witness the existence of those nasal vowels (rend 'order', gomba 'mushroom', etc.). The author reviews the shared conclusion of traditional Slavistics and Hungarian historical linguistics, and shows why and how that 
282 Horváth László: A szláv nazális magánhangzót képviselő jövevényszavak átvételének...

conclusion is debated by ANDRÁs ZOLTÁN, professor of Slavistics at the Budapest university. The other topic of the paper, closely connected with the first, is a method of calculation that a Slavist of Szeged, MiHÁLY KOCSIS, proposed on the basis of the time of attestation of loanwords in Hungarian reflecting the existence of Slavic nasal vowels. The present author claims that that experiment cannot have been successful and convincing due to the small number and limited length of the extant Old Hungarian (9-14th century) texts.

Keywords: Slavic nasal vowels, denasalization, Slavic loanwords, timing, method of calculation based on attestedness.

HORVÁTH LÁSZLÓ MTA Nyelvtudományi Intézet 